\title{
Pawel Antkowiak
}

Uniwersytet im. Adama Mickiewicza w Poznaniu

\section{Czy to koniec zawodów prawniczych $w$ Europie - przypadek Polski}

D PEWNEgo CZASU w EuRoPIE toczy się dyskusja na temat dostępu nych usług prawniczych, ile ich dostępności. Dyskusja ta nie ominęła także Polski, w której zastanawiano się przede wszystkim nad zreformowaniem samorządów zawodowych zawodów prawniczych, zwracając szczególną uwagę na samorząd adwokacki oraz samorząd radców prawnych. Zanim jednak przedstawione zostaną argumenty mówiące o potrzebie zreformowania obecnie funkcjonującego systemu w Polsce, warto spojrzeć, jak wygląda rzeczywista dostępność do usług prawniczych w krajach Unii Europejskiej.

Zgodnie z „Raportem o dostępności pomocy prawnej” przygotowanym przez Naczelną Radę Adwokacką w dniu 12 stycznia 2010 roku Polska zajmuje dwunaste miejsce wśród dwudziestu siedmiu państw członkowskich Unii Europejskiej, co w kontekście wcześniejszych statystyk jest rzeczywistą i realną poprawą tego stanu. Wyprzedzają nas takie kraje jak: Włochy, Hiszpania, Grecja, Luksemburg, Portugalia, Wielka Brytania, Cypr, Niemcy, Bułgaria, Belgia i Węgry. Pozostałe kraje członkowskie, czyli: Malta, Dania, Holandia, Słowacja, Czechy, Rumunia, Francja, Austria, Słowenia, Estonia, Szwecja, Łotwa, Litwa, Irlandia oraz Finlandia pozostają w tyle za Polską. Na dzień dzisiejszy, zgodnie z danymi podawanymi przez Naczelną Izbę Adwokacką w 2010 roku w Polsce usługi prawne świadczyć będzie 37700 prawników (zgodnie z dyrektywą 98/5/EC). W tego rodzaju zestawieniach bierze się jedynie pod uwagę dwa zawody prawnicze, a mianowicie zawód adwokata oraz radcy prawnego. Biorąc pod uwagę liczbę ludności Polski, która zgodnie z danymi przedstawionymi przez Główny Urząd Statystyczny w dniu 30 czerwca 2009 roku wynosi 38154000 mieszkańców to okazuje się, iż na 1 dyplomowanego prawnika przypada w Polsce 1012 obywateli. Inaczej mówiąc na 100 ooo obywateli 
w Polsce przypada 99 prawników1 ${ }^{1}$ Szczegółowe zestawienie dotyczące dostępności usług prawniczych w krajach członkowskich całej Unii Europejskiej przedstawia wykres 1.

Wykres 1. Liczba mieszkańców przypadających na jednego prawnika postugujacego się tytutem zawodowym zgodnie z dyrektywa 98/5/EC (adwokaci i radcy prawnicy)

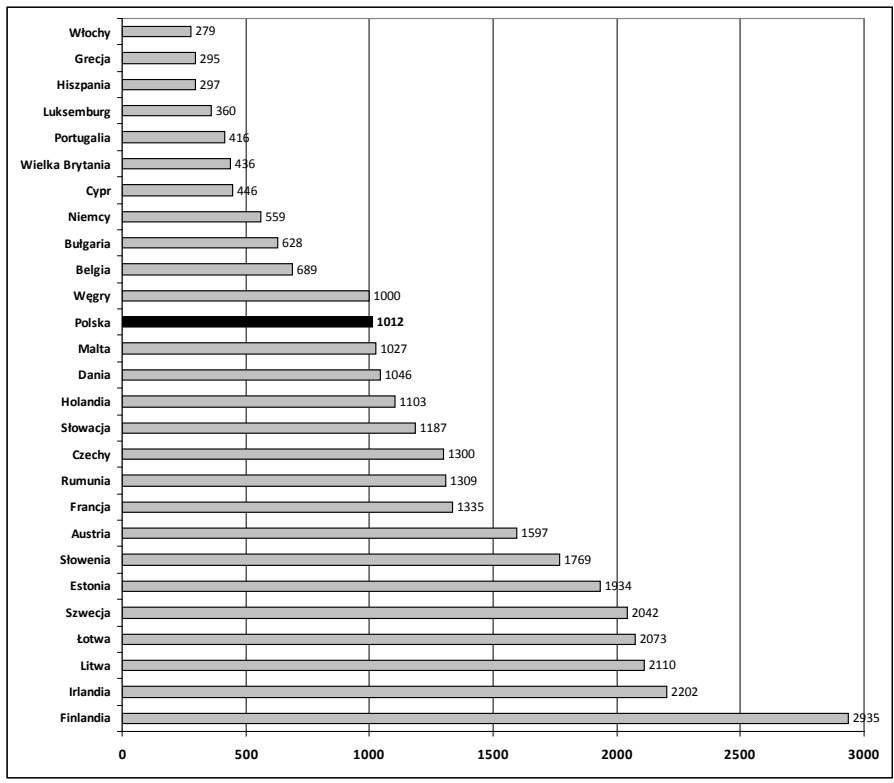

Źródło: Raport o dostępności pomocy prawnej w Polsce, http://adwokatura.pl/newsletter/gfx/File/o01/DANE.pdf, 15.02.2010, s. 3.

Warto powiedzieć, iż w ostatnich latach nastąpił rzeczywisty przyrost liczby prawników, świadczących różnorakie usługi prawne. Dla zobrazowania powyższego trendu warto wskazać na dane dotyczące zawodu adwokata. Od roku 2005, gdy ogólna liczba adwokatów wynosiła 7933, do roku 2010 liczebność stanu adwokackiego wzrosła o około 1/3. Naczelna Rada Adwokacka przewiduje ponadto, iż jeśliby uwzględnić liczbę aplikantów, to w kolejnych latach liczba adwokatów będzie systematycznie wzrastać. Naczelna Rada Adwokacka przyjęła, że jeżeli zdawalność egzaminu adwokackiego będzie zbliżona do

${ }^{1}$ Raport o dostępności pomocy prawnej $w$ Polsce, http://adwokatura.pl/newsletter/gfx/File/oo1/DANE.pdf, 15.02.2010 r., s. 3. 
tej z roku 2009, ogólna liczba adwokatów w roku 2013 powinna wynieść około 14500 osób. Jeśli podobny trend utrzymałby się również w przypadku radców prawnych, to w 2013 roku mielibyśmy 36000 osób parających się tym właśnie zawodem. Łącznie zatem za trzy lata mielibyśmy w Polsce 50500 prawników zgodnie z założeniami dyrektywy 98/5/EC, a więc adwokatów i radców prawnych i plasowalibyśmy się w pierwszej dziesiątce państw UE ${ }^{1}$.

Nie należy jednak zapominać, że pomoc prawną w III Rzeczypospolitej świadczą nie tylko adwokaci i radcy prawni, lecz również przedstawiciele innych, bardziej wyspecjalizowanych zawodów prawniczych. W ramach specjalistycznej działalności prawnej w Polsce funkcjonuje również zawód doradcy podatkowego, komornika, notariusza oraz rzecznika patentowego. Gdyby zliczyć przedstawicieli wszystkich tych profesji włącznie z adwokatami oraz radcami prawnymi, to liczba osób świadczących usługi prawne wraz z aplikantami wyżej wskazanych zawodów wynosi w Polsce ponad 68000 osób. Szczegółowe zestawienie osób świadczących wykwalifikowaną pomoc prawną w Polsce zawiera tabela 1.

Tabela 1. Ogólna liczba osób wykonujących $w$ Polsce zawody prawnicze

\begin{tabular}{|l|c|c|c|}
\hline \multicolumn{1}{|c|}{ Zawód } & $\begin{array}{c}\text { Wykonujący } \\
\text { zawód }\end{array}$ & Aplikanci & Razem \\
\hline Adwokaci & 10524 & 5500 & 16024 \\
\hline $\begin{array}{l}\text { Doradcy } \\
\text { podatkowi }\end{array}$ & 8714 & 0 & 8714 \\
\hline Komornicy & 788 & 400 & 1188 \\
\hline Notariusze & 2074 & 1696 & 3770 \\
\hline Radcy prawni & 26050 & 12000 & 38050 \\
\hline $\begin{array}{l}\text { Rzecznicy } \\
\text { patentowi }\end{array}$ & 938 & 128 & 1066 \\
\hline
\end{tabular}

Źródło: Raport o dostępności pomocy prawnej w Polsce, http://adwokatura.pl/newsletter/gfx/File/oo1/DANE.pdf, 15.02.2010, s. 5.

Dyskusja na temat dostępu poszczególnych osób do zawodów prawniczych koncentruje się wokół zagadnienia liczby osób świadczących usługi prawne w stosunku do ogólnej liczby mieszkańców. Pomijany jest bardzo istotny element, jakim jest jakość świadczonych usług. Aby jednak dyskutować na temat zawodów prawniczych w Pol- 
sce, warto spojrzeć, jak wygląda organizacja wykonywania tych zawodów w naszym kraju.

Zawody prawnicze wymienione w tabeli 1 zaliczane są do tzw. wolnych zawodów. Krystyna Wojtczak uznaje, że wolny zawód to osobiste i systematyczne wykonywanie wewnętrznie spójnego zespołu czynności o charakterze intelektualnym, wymagających wysokich kwalifikacji, systematycznie, w zamian za honorarium bezinteresownie ustalone, służące zapewnieniu świadczeń i usług klientom oraz ochronie istotnych wartości interesu ogólnego, zgodnie z obowiązującymi normami prawnymi i zasadami etycznymi ${ }^{2}$.

Próbę zdefiniowania wolnego zawodu podjął również Józef Filipek, który uznał, że osoby wykonujące wolny zawód powinny mieć wysokie kwalifikacje oraz przygotowanie, ponieważ działania podejmowane przez przedstawicieli tych profesji są niezwykle złożone. Władza publiczna nie powinna ingerować w metody działań stosowane w obrębie wolnych zawodów. Ponadto wolne zawody muszą być wykonywane samodzielnie oraz w sposób nieskrępowany. Samodzielność działania powoduje powstanie szczególnej więzi pomiędzy osobą wykonującą wolny zawód a odbiorcą jej świadczeń i usług, która to więź oparta jest na zaufaniu. Każdy wolny zawód powinien mieć swój samorząd, zapewniający samodzielność i niezależność wobec administracji rządowej. Podobne rozważania prowadzą również inni badacze, którzy podkreślają między innymi, iż zadaniem przedstawicieli wolnych zawodów jest świadczenie określonych usług o charakterze pozamaterialnym, w sferze dóbr publicznych i wartości o charakterze idealnym w życiu społecznym. Świadczenie tego rodzaju usług oparte jest na zawodowo-gospodarczej samodzielności i niezależności działającego podmiotu. Podmiot ten wykorzystuje własne zdolności i umiejętności twórcze, nie będąc formalnie podporządkowanym woli osób trze$\operatorname{cich}^{3}$. Należy jednak zaznaczyć, że polski ustawodawca nie uregulował normatywnie tego pojęcia, pozostawiając to zadanie doktrynie prawnej.

W polskiej literaturze pojęcie wolnego zawodu występuje rzadko i często pojawia się jedynie dla zobrazowania pewnej grupy zawodów, które wskazane zostały w ustawie o podatku dochodowym. Znacznie więcej miejsca w polskiej literaturze przedmiotu poświęca się innemu

${ }^{2}$ J. Jacyszyn, Wykonywanie wolnych zawodów w Polsce, Warszawa 2004, s. 21.

${ }^{3}$ M. Szydło, Nabywanie uprawnień do wykonywania wolnych zawodów, „Państwo i Prawo" 2002, z. 7, s. 51. 
pojęciu, a mianowicie pojęciu samorządu zawodowego, które posiada umocowanie konstytucyjne. W art. 17 Konstytucji Rzeczypospolitej Polskiej z dnia 2 kwietnia 1997 r. stwierdzono bowiem, że $W$ drodze ustawy można tworzyć samorządy zawodowe, reprezentujące osoby wykonujące zawody zaufania publicznego i sprawujace pieczę nad należytym wykonywaniem tych zawodów $w$ granicach interesu publicznego i dla jego ochrony. Funkcjonowanie zawodów, które w literaturze europejskiej bardzo często określane są jako zawody wolne, zostało zorganizowane na zasadzie przymusowego samorządu korporacyjnego.

Obecnie funkcjonujący model administracji zakłada jej wykonywanie zarówno przez aparat scentralizowanej administracji rządowej, jak również wieloraki układ organów czy instytucji działających samodzielnie i wykonujących powierzone im w drodze ustaw zadania publiczne w imieniu własnym i na własną odpowiedzialność. Koncepcja ta zakłada wielość podmiotów publiczno-prawnych uczestniczących obok państwa i jego organów w sprawowaniu władzy publicznej oraz wykonywaniu administracji. Oprócz jednostek obligatoryjnych o podstawowym znaczeniu, jak na przykład jednostki samorządu terytorialnego, administracja jest również wykonywana przez samorządy zawodowe, gospodarcze czy zakłady administracyjne. Nie ulega wątpliwości, iż nowy model organizacji administracji w Polsce stanowi przeciwieństwo systemu narzuconego w latach czterdziestych minionego stulecia i bez powodzenia reformowanego przez cały okres Polski Ludowej ${ }^{4}$.

Bardzo istotną rolę w systemie reprezentowania interesów określonych grup społecznych odgrywa samorząd zawodowy. Zgodnie z założeniami teoretycznymi samorząd zawodowy to organizacyjna forma zrzeszania się osób wykonujących ten sam zawód, której celem jest m.in. reprezentowanie ich interesów wobec władz państwowych, doskonalenie zawodowe i czuwanie nad etyką wykonywania zawodu oraz ochrona socjalna tychże osób, a także realizowanie szeregu zadań typowych dla związków publicznoprawnych. To właśnie publicznoprawny zakres działań samorządu zawodowego decyduje o jego istocie i wyróżnia go spośród innych organizacji o charakterze typowo zrzeszeniowym $^{5}$.

${ }^{4}$ M. Cherka, Decentralizacja - czy „reaktywacja” pojęcia jest groźna?, „Studia Iuridica” 2004, t. XLIII, s. $15-16$.

${ }^{5}$ R. Kmieciak, Formy organizacyjne samorzadu $w$ III Rzeczypospolitej, [w:] Polska $w$ XX wieku. Politologiczna charakterystyka dokonań i perspektyw rozwoju, red. 
Dodać również należy, że samorządy zawodowe tworzone są przez profesje, które ze względu na swoje społeczne znaczenie wymagać muszą najwyższych kwalifikacji merytorycznych i moralnych dla ochrony tych zawodów i ich przedstawicieli oraz dla umacniania interesu społecznego. Powstawanie tego typu struktur i przyznanie im uprawnień władczych traktowane może być jako dowód uznania przez państwo ich kompetencji w dziedzinach realizacji ustawowych zadań publicznych ${ }^{6}$.

Rok 1989 przyniósł wiele zmian społeczno-politycznych, powodując między innymi aktywizację różnorakich środowisk zawodowych. Wiele środowisk zawodowych postanowiło oprzeć swoje funkcjonowanie na publiczno-prawnych formach działania. Jednakże ustanowienie samorządu zawodowego o charakterze publicznoprawnym leżało w gestii państwa7. Zakres, w jakim państwo przekazało władztwo publiczne samorządowi zawodowemu obejmuje:

- reprezentowanie interesów określonych zawodów wobec władz państwowych - najlepszym przykładem tego typu działań jest opiniowanie projektów aktów prawnych, a także zgłaszanie spostrzeżeń i wniosków z tego zakresu;

- nadzór nad należytym wykonywaniem zawodu - dotyczący m.in. reglamentowania dostępu do określonych profesji i prowadzenie rejestru osób mających prawo wykonywania zawodu; w tej mierze po stronie samorządu znajduje się szereg prerogatyw z zakresu prawa administracyjnego;

- kształtowanie zasad i czuwanie nad etyką wykonywania zawodu - w przypadku tej zasady (jak i kolejnej) to samorząd zawodowy ustala zasady deontologii zawodowej, a także poprzez sprawowanie sądownictwa dyscyplinarnego stara się wpływać na postawy swoich członków; ingerencja ta bywa czasami daleko idąca (ograniczenie wykonywania zawodu bądź pozbawienie prawa wykonywania zawodu);

- organizowanie i prowadzenie sądownictwa dyscyplinarnego;

R. Kmieciak, Poznań 2000, s. 207.

${ }^{6}$ A. Lemiszowska, Społeczna misja samorzadu zawodowego, [w:] Wartości $i$ interesy a społeczeństwo obywatelskie, red. M. Kwiatkowski, „Rocznik Lubuski” 2003, t. XXIX, s. 173.

7 R. Kmieciak, Ustrój i zadania samorządu zawodowego, [w:] Samorząd w Polsce - istota, formy, zadania, red. S. Wykrętowicz, Poznań 2008, s. 352. 
- doskonalenie zawodowe i określanie programów kształcenia w danym zawodzie - dbają one o jakość świadczonych usług i z tego względu organizują one system szkoleń ${ }^{\text {. }}$.

Obecnie w polskim systemie prawnym obowiązują uregulowania rangi ustawowej powołujące następujące samorządy zawodowe: adwokacki, radców prawnych, lekarski, lekarsko-weterynaryjny, notarialny, pielęgniarek i położnych, aptekarski, biegłych rewidentów, doradców podatkowych, komorniczy, architektów, inżynierów budownictwa, urbanistów, rzeczników patentowych, psychologów, kuratorów sądowych, diagnostów laboratoryjnych ${ }^{9}$. Wśród wymienionych wyżej samorządów można wyróżnić korporacje reprezentujące zawody prawnicze i związane $\mathrm{z}$ wykonywaniem prawa:

- Samorząd adwokacki, powołany na podstawie ustawy z dnia 26 maja 1982 r. prawo o adwokaturze (Dz. U. $1982 \mathrm{Nr}$ 16, poz. 124 z późn. zm.). Samorząd zawodowy adwokatów posiada strukturę trójszczeblową, składającą się z Naczelnej Rady Adwokackiej - jako najwyższego szczebla, izb adwokackich - jako szczebla okręgowego oraz zespołów adwokackich jako szczebla najniższego. Adwokatura, którą stanowi ogół adwokatów i aplikantów adwokackich, powołana jest do udzielania pomocy prawnej, współdziałania w ochronie praw i wolności obywatelskich oraz kształtowania i stosowania prawa.

- Samorząd radców prawnych, powołany na podstawie ustawy z dnia 6 lipca 1982 r. o radcach prawnych (Dz. U. 1982 Nr 19, poz. 145 z późn. zm.). Mimo, iż organizacja tej korporacji zawodowej jest dwuszczeblowa, to należy powiedzieć, iż jej struktura oraz kompetencje są bardzo zbliżone do organizacji samorządu adwokackiego. Na szczeblu centralnym funkcjonuje Krajowa Izba Radców Prawnych, zaś w terenie okręgowe rady radców prawnych, których zasięg terytorialny podobnie jak w przypadku samorządu zawodowego adwokatów odpowiada podziałowi terytorialnemu administracji sądownictwa.

- Samorząd notarialny, powołany na podstawie ustawy z dnia 14 lutego 1991 r. prawo o notariacie (Dz. U. 1991 Nr 22,

${ }^{8}$ R. Kmieciak, Asymetria $w$ rozwoju samorzad zawodowego i gospodarczego $w$ Polsce, [w:] Spór o samorząd gospodarczy w Polsce, red. S. Wykrętowicz, Poznań 2005, s. 93.

${ }_{9}$ S. Bułajewski, Samorzady zawodowe i gospodarcze jako samorządy specjalne, [w:] Wolność zrzeszania się w Polsce, red. M. Chmaj, Warszawa 2008, s. $204-222$. 
poz. 91, z późn. zm.). Samorząd ten ma organizację dwuszczeblową, obejmuje izby notarialne i Krajową Radę Notarialną, które posiadają osobowość prawną. Izbę notarialną stanowią notariusze prowadzący kancelarię w okręgu danego sadu apelacyjnego.

- Samorząd doradców podatkowych, powołany na podstawie ustawy z dnia 5 lipca 1996 r. o doradztwie podatkowym (Dz. U. 1996 Nr 102, poz. 475 z późn, zm.). Samorząd ten składa się z jednego szczebla, który tworzy Krajowa Izba Doradców Podatkowych posiadająca osobowość prawną.

- Samorząd komorniczy, powołany na podstawie ustawy z dnia 29 lipca 1997 r. o komornikach sądowych i egzekucji (Dz. U. 1997 Nr 133, poz. 882 z późn. zm.). Zawód komornika na podstawie tej ustawy otrzymał nowy status, ponieważ poprzednio komornicy, podobnie jak notariusze, wykonywali zawód jako pracownicy administracji publicznej. Organizacja tego samorządu jest dwuszczeblowa. Organami posiadającymi osobowość prawną jest Krajowa Rada Komornicza i izby komornicze.

- Samorząd rzeczników patentowych, powołany na podstawie ustawy z dnia 11 kwietnia 2001 r. o rzecznikach patentowych (Dz. U. $2001 \mathrm{Nr}$ 49, poz. 509 z późn zm.). Zgodnie z zapisami art. 42 tej ustawy, przynależność do Polskiej Izby Rzeczników Patentowych zarówno rzeczników jak i aplikantów jest obowiązkowa. Organami tej korporacji są: Krajowy Zjazd Rzeczników Patentowych, Krajowa Rada Rzeczników Patentowych, Komisja Rewizyjna, Odwoławczy Sąd Dyscyplinarny, Sąd Dyscyplinarny, Rzecznik Dyscyplinarny oraz okręgowe zgromadzenia rzeczników patentowych ${ }^{10}$.

Wymienione zawody zaliczane są do zawodów zaufania publicznego. Przynależność do samorządu osób wykonujących wymienione wyżej profesje jest obowiązkowa, a możliwość ich wykonywania uzależniona jest od wpisania na listę zawodową. Ustawy regulujące działalność samorządów zawodowych określają strukturę tych samorządów, ilość szczebli w strukturze oraz ustanawiają organy korporacyjne. W ustawach tych określone są zadania państwa, które ustawodawca zdecydował się przekazać do realizacji organom samorządów za-

${ }^{10}$ M. A. Waligórski, S. Pawłowski, Samorząd zawodowy i gospodarczy $w$ Polsce, Poznań 2005, s. 71. 
wodowych, a także określone są kompetencje, jakie w celu wykonania tych zadań ustawodawca przekazał organom korporacyjnym. Jest to spełnienie idei decentralizacji - samorząd zawodu zaufania publicznego nabywa od państwa szereg kompetencji, by prawidłowo mógł spełniać swoje funkcje, a jednocześnie przejmuje niemal pełną odpowiedzialność za te działania.

Należy też powiedzieć, że w ostatnich latach w Polsce samorząd zawodowy poddawany jest ostrej krytyce zarówno przez społeczeństwo, jak i samych jego członków. Wokół jego funkcjonowania krąży wiele mitów i nieporozumień, które często zamazują istotę samorządności. Przede wszystkim widać wyraźnie, że opinia społeczeństwa o różnych samorządach zawodowych jest coraz bardziej negatywna, bowiem rola społeczna, jaką przypisuje społeczeństwo danej grupie zawodowej, ma niezwykle istotne znaczenie dla jej funkcjonowania. Istotną częścią działalności samorządów zawodowych jest dbanie o wysokie standardy moralne i etyczne ${ }^{11}$.

Zdaniem obserwatorów tych niepokojących zjawisk w ramach polskich samorządów zawodowych, brak zaufania społecznego względem ich przedstawicieli może się stać przysłowiowym „gwoździem do trumny" samorządów funkcjonujących w obecnym kształcie i na obecnych zasadach. Warunkiem sprawnego działania samorządu zawodowego jest bowiem zaspokajanie potrzeb społecznych, a brak takich działań objawia się właśnie spadkiem zaufania do przedstawicieli danych zawodów. W dyskusji na temat samorządu zawodowego wskazuje się często na ograniczanie młodym ludziom dostępu do zawodu. Członkowie korporacji mówią natomiast, że przepisy utrudniające drogę zawodową mają charakter ochrony klientów, którzy zasługują przecież na obsługę przez wysoko wykwalifikowanych specjalistów ${ }^{12}$. Ponadto poddaje się w wątpliwość to, czy samorząd zawodowy zawodów prawniczych nie ogranicza konkurencji na rynku medycznym i nie stanowi swoistego rodzaju prawnie usankcjonowanego monopolu. Restrykcyjne zasady uzyskiwania prawa wykonywania zawodu oraz reglamentowany dostęp do usług powoduje, zdaniem niektórych, nieład na rynku usług prawniczych. Obrońcy samorządów prawniczych twierdzą, że przecież chodzi przede wszystkim o jakość usług, a nie o ich ilość.

${ }^{11}$ M. Rutkowska, Samorzady zawodowe $w$ okresie transformacji $w$ Polsce, Wrocław 2004, s. $79-80$.

${ }^{12}$ K. Radziwil, Nie ma barier $w$ dostępie do zawodu lekarza, „Rzeczpospolita” 28.06.2007. 
W ostatnim czasie, korporacje prawnicze coraz szerzej otwierają drzwi dla młodych adeptów poszczególnych zawodów. Najlepszym przykładem tego rodzaju tendencji jest samorząd radców prawnych. Samorząd radców prawnych uznał bowiem, że dostęp do aplikacji powinien być umożliwiony wszystkim zainteresowanym absolwentom wydziałów prawa bez limitów i egzaminów wstępnych. Sprawdzianem kwalifikacji warunkującym świadczenie pomocy prawnej w zakresie przewidzianym przez ustawodawcę dla zawodów zaufania publicznego nadal pozostać powinien egzamin zawodowy poprzedzony ukończeniem aplikacji prowadzonej przez samorząd. Przedstawiciele tego samorządu podkreślają, że wszelkie zmiany w zasadach dostępu do tego właśnie zawodu leżą w gestii ustawodawcy. Władze tej korporacji zawodowej zapowiadają, iż w niedalekiej przyszłości złożą stosowny projekt ustawy, który doprowadziłby do spełnienia ich postulatów ${ }^{13}$.

Jednocześnie warto zaznaczyć, iż korporacje prawnicze podkreślają, że bardzo ważnym elementem edukacji zawodowej jest odbycie stosownej aplikacji. Na poparcie swoich racji przytaczają oni wyniki egzaminów osób, które odbyły aplikację, oraz osób, które takiej aplikacji odbywać nie musiały. Dla przykładu adwokacki egzamin zawodowy dla aplikantów zdało w 2009 roku 78\% osób, które podeszło do egzaminu. Natomiast ministerialny egzamin adwokacki dla osób, które nie odbywały aplikacji zdało zaledwie $28 \%$ osób. Pokazuje to bardzo wyraźnie, że odbycie aplikacji w znaczący sposób wpływa na poziom zdawalności egzaminu zawodowego.

Nie ulega wątpliwości, że przynależność do grupy wykonującej zawód zaufania publicznego w Polsce powinna być formą nobilitacji społecznej wynikającej z obowiązujących w środowisku wysokich standardów profesjonalnych i nienagannej postawy etycznej. Funkcjonujące samorządy zawodowe są z jednej strony administratorem spraw korporacji zawodowych oraz organizatorem życia społecznego w ramach swojej grupy zawodowej, z drugiej zaś strony zajmują się wykonywaniem funkcji z zakresu administracji publicznej. Są jednym z integralnych elementów państwa zorganizowanego w oparciu o zasadę demokratycznego państwa prawa. Posiadanie przez daną profesję statusu samorządu zawodowego powinno mobilizować do wytężonej pracy po to, aby nie był to jedynie pusty zapis ustawowy a rzeczywisty samo-

${ }^{13}$ Stanowisko samorządu radców prawnych $w$ sprawie poszerzenia dostępu do zawodu i likwidacji egzaminu wstępnego na aplikację, http://www.edukacjaprawnicza.pl/images/files/stanowiskokrrpwsprawieaplikacjiradcow skiej.doc, 15.02.2010. 
rząd zawodowy. Bezsporne jest również to, iż nie można doprowadzić do zachwiania równowagi pomiędzy interesem społecznym a partykularnym interesem danej profesji, bowiem samorząd zawodowy winien chronić zarówno jego członków, jak i społeczeństwo przed nieprawidłowościami w danym zawodzie.

Nadszarpnięte dobre imię korporacji prawniczych w Polsce może doprowadzić w dłuższej perspektywie czasowej do likwidacji tej formy samorządu oraz przeniesienia uprawnień posiadanych dotychczas przez samorządy prawnicze na rzecz władz państwowych. W ostatnim czasie pojawiają się głosy, aby zlikwidować tzw. „monopol samorządu zawodowego". Proponuje się między innymi likwidację obowiązkowej przynależności do samorządu zawodowego w ogóle, co w moim przekonaniu stoi w wyraźnej sprzeczności z ideą samorządu zawodowego. Jednakże pomysł ten znajduje coraz więcej zwolenników. Na listę propagatorów tego pomysłu wpisał się w ostatnim czasie Rzecznik Praw Obywatelskich Janusz Kochanowski, który skierował do Trybunały Konstytucyjnego wniosek o sprawdzenie zgodności z Konstytucją zasady obligatoryjnej przynależności do samorządu zawodowego. Poddał on w ten sposób w wątpliwość korporacyjny charakter funkcjonowania samorządu zawodowego w Polsce ${ }^{14}$. W przekonaniu członków poszczególnych korporacji prawniczych byłby to nieuchronny koniec samorządów w dotychczasowej formie. Ponadto likwidacja struktur samorządu doprowadziłaby również do społecznej degradacji członków poszczególnych profesji. Dyskusja publiczna w Polsce nad przyszłością samorządów zawodowych nadal trwa.

Podobne rozważania na temat funkcjonowania zawodów prawniczych trwają w innych państwach europejskich. W Francji dyskutuje się nad reformą zawodu, która zdaniem jej autorów powinna zrewolucjonizować rynek usług prawniczych. Jean-Michel Darrois, wspólnik we francuskiej kancelarii Darrois Villey Maillot Brochier, stanął na czele komisji nauczycieli akademickich i ludzi biznesu, której zadaniem miało być przeanalizowanie francuskich przepisów dotyczących wykonywania zawodów prawniczych. Celem podjętych działań ma być stworzenie nowoczesnej profesji prawniczej poprzez promowanie głębokiej reformy struktur profesjonalnych firm prawniczych dla zwiększenia ich konkurencji na rynku krajowym i międzynarodowym oraz poprawy jakości usług prawniczych świadczonych klientom. Raport zawiera też propozycję kilku rozwiązań mających na celu zre-

${ }^{14}$ D. Frey, T. Pietryga, Przeciw korporacjom, „Rzeczpospolita” 12.01.2009. 
formowanie systemu usług prawniczych oraz poprawę jego dostępności z jednoczesnym efektywniejszym zarządzaniem kosztami tego systemu. Jest to przede wszystkim:

- $\quad$ poszerzenie i zreformowanie francuskiej praktyki prawniczej poprzez zjednoczenie i koordynowanie wszystkich zawodów prawniczych w celu ograniczenia samej liczby różnych zawodów prawniczych wykonywanych we Francji i uczynienia rynku bardziej przejrzystym i zrozumiałym;

- ułatwienie tworzenia zawodowych spółek partnerskich, w tym z francuskimi notariuszami, oraz dopuszczenie pewnych możliwości dzielenia się honorariami przez francuskich notariuszy i adwokatów;

- $\quad$ poszerzenie współpracy między zawodami prawniczymi;

- dopuszczenie tworzenia wielodyscyplinarnych spółek dzielących się zyskami;

- zapewnienie większej pomoc prawną oskarżonym i pozwanym.

Zatem postulaty przedstawione powyższym raporcie są bardzo podobne do tych, które pojawiają się w polskiej debacie publicznej i politycznej.

Dyskusja toczy się również w Irlandii, gdzie zakres uprawnień irlandzkich solicytorów przypomina do złudzenia uprawnienia przysługujące w Polsce adwokatom. Zawód ten jest nieco zbliżony także do zawodu radcy prawnego, notariusza czy doradcy podatkowego. Większość solicytorów w Irlandii funkcjonuje w oparciu o prywatne kancelarie, ale mogą oni również wybrać karierę pracownika w przedsiębiorstwie handlowym, przemysłowym czy w urzędzie państwowym. Solicytorzy mają prawo reprezentować swoich klientów (zarówno osoby fizyczne, jak i osoby prawne) przed sądami i innymi organami powołanymi do rozstrzygania spraw. W ramach działań podobnych do doradztwa podatkowego czy notariatu, solicytor zajmuje się sporządzaniem aktów przeniesienia własności, dzierżawy i innych umów. Solicytorzy sporządzają również testamenty, zarządzają funduszami spadkowymi czy obsługują zobowiązania podatkowe. Całość nadzoru nad uzyskaniem pełni uprawnień zawodowych spoczywa w rękach Stowarzyszenia Prawników Irlandii. Przyszły solicytor ma do pokonania następujące etapy: egzamin wstępny, tak zwany Pierwszy Egzamin Irlandzki, część pierwsza egzaminu końcowego, praktyka zawodowa trwająca 24 miesiące, kursy praktyki zawodowej, podzielone na część pierwszą i część drugą, tak zwany Drugi Egzamin Irlandzki. Po zakoń- 
czeniu wszystkich stadiów edukacji, aplikant automatycznie otrzymuje od Stowarzyszenia Prawników Irlandii formularz wniosku o wpis na listę solicytorów. Niezbędne jest jednak złożenie przez patrona przyrzeczenia obejmującego zapewnienie, iż ubiegający się o wpis jest osobą godną i należycie przygotowaną ${ }^{15}$. Dyskusja dotyczy przede wszystkim tego, czy nie należałoby uelastycznić tego systemu tak, aby liczba osób świadczących usługi prawne wzrosła. Pomimo tego, że zawód solicytora jest zawodem powszechnie poważanym w społeczeństwie irlandzkim, to nie ulega wątpliwości, że dostęp do usług prawnych w Irlandii jest dwukrotnie mniejszy aniżeli w Polsce, co wyraźnie pokazuje wykres 1 .

Jeśliby spojrzeć na tematykę dyskusji wokół zawodów prawniczych na kontynencie europejskim, to koncentruje się ona głównie wokół konieczności zwiększenia dostępu do usług prawnych. Oczywiście na mapie Europy widać znaczne zróżnicowanie pod tym względem, a dyskusje są najbardziej burzliwe tam, gdzie liczba prawników w stosunku do liczby mieszkańców jest niska. W Europie istnieją wyraźnie podobieństwa, ale i różnice w organizacji życia zawodowego przedstawicieli różnych profesji prawniczych w poszczególnych krajach europejskich.

Dokąd doprowadzi ta dyskusja w Polsce? Otóż wydaje się, że tematyka dostępu do usług prawniczych towarzyszyć nam będzie przez jakiś czas. W Polsce oscyluje ona jednak nie tylko wokół zagadnień związanych z liczbą prawników na polskim rynku, ale również z jakością świadczonych przez nich usług. Dyskusja ta w Polsce jest nierozerwalnie związana z funkcjonowaniem samorządów zawodowych zawodów prawniczych. Jaka jest zatem przyszłość samorządów zawodowych? Nie ulega wątpliwości, że kluczem dalszego rozwoju samorządności zawodów zaufania publicznego będzie odzyskanie dobrego imienia i zarazem zaufania społecznego, które zostało poważnie naruszone. Wyraz tego rodzaju dążeniom dali radcy prawni, którzy uznali, iż celem strategicznym zawodu i samorządu jest odzyskanie, a następnie utrzymanie wysokiego autorytetu społecznego niezbędnego dla zawodów zaufania publicznego, świadczących pomoc prawną w Rzeczypospolitej Polskiej. Radcy prawni uważają również, że najlepsze dla

${ }^{15}$ E. Stawicka, Droga do zawodu solicytora $w$ Irlandii, „Palestra” 2003, nr 11/12, S. $196-200$. 
obu korporacji byłoby połączenie obu zawodów i wspólna reprezentacja ich interesów wobec władz państwowych ${ }^{16}$.

Należy mieć nadzieję, iż członkowie poszczególnych korporacji zrozumieją, że posiadanie samorządu zawodowego i miano charakteru zawodu zaufania publicznego nie jest stanem danym raz na zawsze, bowiem to tak naprawdę od państwa zależy, czy zechce ono przekazać część swoich prerogatyw danym grupom społecznym (zawodowym) ufając, że będą one w stanie lepiej realizować część zadań publicznych. Posiadanie samorządu zawodowego jest swoistego rodzaju przywilejem, który winien być pielęgnowany przez przedstawicieli wyróżnionych w ten sposób zawodów.

\section{SUMMARY}

The SUBJECT OF THIS ARTicLE is access to legal services in Europe, demonstrated on the basis of Polish solutions in the field. The legal professions operate as corporations called professional self-government. The theoretical assumptions behind professional self-government is that it guarantees high ethical and professional standards, as well as balance between free professional practice and the quality of services provided. Its existence and operation is therefore an integral part of the democratic rule of law.

\section{NotA O AUTORZE}

Pawel Antkowiak [pawel.antkowiak@amu.edu.pl] - doktorant na Wydziale Nauk Politycznych i Dziennikarstwa UAM w Poznaniu. Jego zainteresowania naukowe oscylują wokół zagadnień związanych z funkcjonowaniem samorządu terytorialnego, zawodowego i gospodarczego, polityką regionalną Unii Europejskiej, a także wpływem nowoczesnej technologii na procesy demokratyczne.

${ }^{16}$ Przyszłość zawodu i korporacji - uwarunkowania pozytywnej prognozy: stanowisko Ośrodka Badawczego Radców Prawnych, „Radca Prawny” 2007, r. 20, s. 28 - 31. 